\title{
Did Established Early Warning Signals Predict the 2008 Crises?*
}

\author{
Charis Christofides \\ IMF \\ Theo S. Eicher \\ University of Washington \\ Chris Papageorgiou** \\ IMF
}

April 2015

\begin{abstract}
Over the past 60 years, a voluminous literature has painstakingly developed crises theories and their associated Early Warning Signals. The hallmark of this literature is the consistency with which selected Early Warning Signals, such as the level of reserves and exchange rate appreciations, are presumed to predict different types of crises across countries and time. The diversity of crises theories that motivate Early Warning Signals presents, however, a challenge to empirical implementations. Given that the true model of Early Warning Signals is unknown, omitted variable bias contaminates estimates and confidence levels when the uncertainty surrounding a particular theory has been ignored. After addressing model uncertainty in Early Warning Signal regressions, using an extended version of Frankel and Saravelos (2012) dataset, we do not find a single Early Warning Signal that alerts to all dimensions of the 2008 crisis. Instead, distinct sets of Early Warning Signals identify different dimensions of the crisis: Banking, Balance of Payments, Exchange Rate Pressure, and Recession.
\end{abstract}

JEL Classification: F30, F43.

Keywords: Early Warning Signals, Economic Crises, Model Uncertainty, Banking, Balance of Payments, Exchange Rate Pressure, Recessions.

\footnotetext{
* We thank the special issue editor and two anonymous referees for valuable comments. We also thank Jeff Frankel and George Saravelos for sharing their dataset. Elias Dinopoulos, Jeff Frankel, Ayhan Kose, Alex Mourmouras, George Saravelos, Haris Tsangarides, Hal Varian, and seminar participants at the IMF, the World Bank, the US Treasury Department, the Central Bank of Slovakia, and the Central Bank of Costa Rica provided helpful comments and suggestions. Eicher thanks the Instituto de Investigaciones en Ciencias Económicas and the Department of Economics at the University of Costa Rica for their hospitality during the preparation of the manuscript. Christofides and Papageorgiou acknowledge financial support by the IMF. The views expressed in this study are the sole responsibility of the authors and should not be attributed to the International Monetary Fund, its Executive Board, or its management.
}

** Corresponding author: Chris Papageorgiou, IMF, cpapageorgiou@imf.org. 
"History doesn't repeat itself, but it does rhyme."

- Mark Twain

\section{Introduction}

A voluminous crisis literature has established numerous potential Early Warning Signals. The hallmark of this literature is the remarkable robustness of a select number of Early Warning Signals across country subsamples (developed, emerging, and developing), time periods (1950s-2011s), and crises types (banking, currency, debt, equity, and inflation). ${ }^{1}$ In a detailed survey of 83 published studies over past 60 years, Frankel and Saravelos (2012) document the consensus that "foreign currency reserves" and "exchange rate overvaluations" predict crises with astounding consistency.

The broad consensus in a select group of Early Warning Signals was shaken when none of the established Early Warning Signals alerted to the global 2008 financial crisis. Obstfeld, Shambaugh, and Taylor (2009a, 2009b) find reserves/M2 predicted depreciations but not crises in general and that all other established Early Warning Signals were always statistically insignificant. Rose and Spiegel (2009, 2010, 2011), and Blanchard, Faruqee and Klyuev (2009) find that even reserves did not predict the 2008 crisis. Only Frankel and Saravelos (2012) were able to find support for "foreign currency reserves" and "exchange rate overvaluations" as Early Warning Signals for the 2008 Crisis, but only after waiting for updated 2008 data.

The Frankel and Saravelos (2012) methodology has been drawn into question, however, as their results are based on bivariate regressions. In the absence of comprehensive controls, their results may well be subject to substantial omitted variable bias. More problematically, their dataset features so many missing observations that results from different bivariate regression often represent radically different, often mutually exclusive country samples. Finally, their selection criterion to identify robust Early Warning Signals is arbitrary. Frankel and Saravelos (2012) declare an Early Warning Signal as robust when the regressor is significant in 5 different bivariate regressions.

\footnotetext{
${ }^{1}$ For comprehensive surveys, see Kaminski, Lizondo and Reinhart (1998), Hawkins and Klau (2000), Abiad (2003), Berg, Borensztein and Pattillo (2005), and Frankel and Saravelos (2012).
} 
To obtain robust results in cross-country regressions it is crucial to utilize similar country samples across regression specifications. In addition, since the crisis literature is comprised of numerous competing crisis theories and a vast set of potential crisis Early Warning Signals, it is crucial to address the model uncertainty surrounding the validity of a particular theory. Raftery (1995) shows that confidence levels are inflated when the uncertainty surrounding a theory's validity has been ignored. Leamer (1978) and Raftery (1988) develop the appropriate statistical framework to address model uncertainty as part of the statistical methodology. We employ their Bayesian Model Averaging (BMA) approach to evaluate the validity of alternative theories and the effectiveness of the associated Early Warning Signals. BMA addresses the omitted variable bias in Frankel and Saravelos (2012), model uncertainty in the literature, and biased coefficients due to misspecified crisis regressions.

Rose and Spiegel (2011) previously addressed model uncertainty to some degree by using a multiple-indicator, multiple-cause (MIMIC) approach and utilizing factor analysis and stepwise regressions. In contrast, BMA has been shown to maximize predictive performance while minimizing the total error rate when compared to any individual model, factor analysis of stepwise regressions (Raftery and Zheng, 2003). Ho (2010) used the Rose and Spiegel's (2011) data to address the model uncertainty with Extreme Bound Analysis (Leamer, 1978). Extreme Bounds Analysis examines how extreme estimates are across different models, but the approach lacks a formal statistical backbone. The size of the extreme bounds is hotly contested, however, and has been shown to influence results dramatically (Sala-i-Martin, 1997). Indeed BMA was introduced to economics specifically to address shortcomings of Extreme Bound Analysis (Fernandez, Ley and Steel 2001).

It is important to emphasize at the outset that the aim of this paper not find the best model to explain the 2008 crisis. Instead the purpose of the paper is to examine how well the 2008 crisis could have been predicted using those Early Warning Signals that have been established by the literature in the past sixty years. To do so we apply BMA to the most comprehensive 2008 crisis dataset using the established crisis candidate regressors suggested Frankel and Saravelos (2012). We update the data to incorporate 
crucial data revisions from national accounts, World Bank, and IMF data. In addition, we balance our dataset so that all regressions cover the same country sample.

Aside from the interest for policy makers, there are two reasons why the 2008 crisis is particularly well suited to assess the validity of consensus Early Warning Signals. First, the magnitude of the crisis should evoke strong predictive power for any valid Early Warning Signal. Second, the crisis has been uniquely broad and synchronized across the global economy. This provides a stringent test of whether Early Warning Signals exist that alert for different or all subsets of countries and crises. We find no evidence for any single Early Warning Signal that predicts the various dimensions of the 2008 crisis. In contrast to previous studies of 2008 Early Warning Signals we do find, however, that each dimension of the 2008 crisis is identified by a unique, parsimonious set of Early Warning Signals.

The paper is structured as follows. Section 2 reviews the BMA methodology and motivates its application. Section 3 takes a look at the data sources and introduces the Early Warning Signals employed in our analysis. Section 4 reports and discusses the BMA results, while Section 5 concludes and with a discussion of policy relevant findings.

\section{Uncovering Early Warning Signals Using Bayesian Model Averaging}

Previous approaches to assessing Early Warning Signals have been dominated by researcher-selected regression specifications (see the surveys of Abiad, 2003; Hawkins and Klaw, 2000; Collins, 2003; and Frankel and Saravelos, 2012). Their methodologies can be grouped into four categories. One approach uses probit/logit techniques when crisis indicators involve incidence thresholds (e.g., Eichengreen, Rose and Wypslosz, 1995). Alternatively, non-parametric signaling approaches are used to identify crises via threshold values for sets of hand-picked Early Warning Signals (e.g., Kaminski, Lizondo and Reinhart, 1998). A third approach splits the sample into researcher-selected crisis and non-crisis countries (e.g., Kamin, 1988). Finally, recent approaches use alternative statistical methods to identify thresholds for Early Warning Signals via regression trees 
(Ghosh and Ghosh, 2003), artificial neural or genetic algorithms (Nag and Mitra, 1999), or Markov switching models (Cerra and Saxena, 2001).

None of the above four approaches consider, however, that either the researcherspecified set of regressions or the researcher-selected regression trees examine only models that arise from theories whose validities are uncertain. When the uncertainty of a theory is ignore point estimates overstate the significance of a particular regressors associated with that theory. The second limitation of previous statistical methodologies is the lack of clear selection criteria to identify robust Early Warning Signals. Some studies identify valid Early Warning Signals when regressors are significant in at least one of their regressions (e.g., Kaminsky, Lizondo and Reinhart, 1998), while others identify valid Early Warning Signals when regressors are significant in the majority of regressions (e.g., Frankel and Saravelos, 2012). Either approach is questionable since it is conditional on the set of regressions that have been run.

In this section we briefly sketch the basic ideas of Bayesian Model Averaging, BMA, which has been developed to address model uncertainty as part of the statistical methodology and it provides for a natural identification of Early Warning Signals. BMA has important statistical properties that address not only inflated t-statistics, but it can also be formally shown that BMA maximizes predictive performance while minimizing the total error rate when compared to any individual model (Raftery and Zheng, 2003). Our exposition follows Eicher, Papageorgiou and Raftery (2011); for a complete survey of BMA approaches, see Raftery, Madigan and Hoeting (1997). BMA bases prediction and inference not on one particular model, but on the weighted average over all the models and theories considered; where the weight is the quality of each model. The approach has the attractive feature that it directly addresses questions that are central to the researcher's interests, such as "what is the probability that a model is correct?" and "how likely is it that a regressor has an effect on the dependent variable?"

For linear regression models, the basic BMA setup is as follows. Given a dependent variable, $Y$, a number of observations, $n$, and a set of candidate regressors, $X_{1}, \ldots, X_{p}$, the variable selection problem is to find the "best" model, or subset of 
regressors. ${ }^{2}$ We denote by $M_{1}, \ldots, M_{K}$ the models considered, where each one represents a subset of the candidate regressors. Often all possible subsets are considered, in which case $K=2^{p}$. Model $M_{k}$ has the form

$$
Y=\alpha+\sum_{j=1}^{p_{k}} \beta_{j}^{(k)} X_{j}^{(k)}+\varepsilon,
$$

where $X_{1}^{(k)}, \ldots, X_{p_{k}}^{(k)}$ is a subset of $X_{1}, \ldots, X_{p}, \beta^{(k)}=\left(\beta_{1}^{(k)}, \ldots, \beta_{p_{k}}^{(k)}\right)$ is a vector of regression coefficients to be estimated, and $\varepsilon \sim N\left(0, \sigma^{2}\right)$ is the error term. We denote by $\theta_{k}=\left(\alpha, \beta^{(k)}, \sigma\right)$ the vector of parameters in $M_{k}$.

The likelihood function of model $M_{k}, \operatorname{pr}\left(D \mid \theta_{k}, M_{k}\right)$, summarizes all the information about $\theta_{k}$ that is provided by the data, $D$. The integrated likelihood (also commonly known as the marginal likelihood) is the probability density of the observable, conditional on the model $M_{k}$, which equals the likelihood times the prior density, $\operatorname{pr}\left(\theta_{k} \mid M_{k}\right)$, integrated over the parameter space so that

$$
\operatorname{pr}\left(D \mid M_{k}\right)=\int \operatorname{pr}\left(D \mid \theta_{k}, M_{k}\right) \operatorname{pr}\left(\theta_{k} \mid M_{k}\right) d \theta_{k} .
$$

The integrated likelihood is the crucial ingredient in deriving each model's weight in the model averaging process. We denote by $\operatorname{pr}\left(M_{k}\right)$ the prior probability that $M_{k}$ is the correct model, given that one of the models considered is the true model. Then, by Bayes' theorem, the posterior model probability of $M_{k}, \operatorname{pr}\left(M_{k} \mid D\right)$, is equal to the model's share in the total posterior mass

$$
\operatorname{pr}\left(M_{k} \mid D\right)=\frac{\operatorname{pr}\left(D \mid M_{k}\right) \operatorname{pr}\left(M_{k}\right)}{\sum_{\ell=1}^{K} \operatorname{pr}\left(D \mid M_{\ell}\right) \operatorname{pr}\left(M_{\ell}\right)} .
$$

The posterior mean and variance of a regression coefficient, $\beta_{j}$, are then given by

\footnotetext{
${ }^{2}$ In one of our exercises the dependent variable is censored ("IMF support"). The statistical theory regarding model averaging under these circumstances has been developed by Viallefont, Raftery and Richardson (2001) and we use their approach below. Most of the details (other than equation 1) are identical to the linear model described above. We refer the interested reader to the above paper for further details.
} 


$$
\begin{gathered}
E\left[\beta_{j} \mid D\right]=\sum_{k=1}^{K} \hat{\beta}_{j}^{(k)} \operatorname{pr}\left(M_{k} \mid D\right), \\
\operatorname{Var}\left[\beta_{j} \mid D\right]=\sum_{k=1}^{K}\left(\operatorname{Var}\left[\beta_{j} \mid D, M_{k}\right]+\left(\hat{\beta}_{j}^{(k)}\right)^{2}\right) \operatorname{pr}\left(M_{k} \mid D\right)-E\left[\beta_{j} \mid D\right]^{2},
\end{gathered}
$$

where $\hat{\beta}_{j}^{(k)}$ is the posterior mean of $\beta_{j}$ under model $M_{k}$, and is equal to zero if $X_{j}$ is not included in $M_{k}$ (Raftery, 1993). Hence the posterior mean is the weighted average of all model-specific posterior means, where the weights equal each model's posterior probabilities. The posterior variance reflects both the weighted average of the withinmodel posterior variances as well as the between-model variation of the posterior means.

The BMA posterior means and variances highlight that when inference is conditioned on a single model, the between-model variation is ignored. Thus a single model overestimates the certainty with which its results may actually reflect the true model parameters. In a decision-making context, such an oversight leads to decisions that are riskier than the decision maker thinks they are. BMA incorporates model uncertainty into the posterior distribution itself, and thus allows the uncertainty itself to be propagated through to final conclusions.

In addition to the posterior means and standard deviations, BMA provides the posterior inclusion probability of a candidate regressor, $\operatorname{pr}\left(\beta_{j} \neq 0 \mid D\right)$, by summing the posterior model probabilities across those models that include the regressor. Posterior inclusion probabilities provide a probability statement regarding the importance of a regressor that directly addresses what is often the researcher's prime concern: "what is the probability that the regressor has an effect on the dependent variable?" The general rule developed by Jeffreys (1961) and refined by Kass and Raftery (1995) stipulates effectthresholds for posterior inclusion probabilities. Posterior inclusion probabilities $<50 \%$ are seen as evidence against an effect, and the evidence for an effect is either weak, positive, strong, or decisive for posterior inclusion probabilities ranging from $50-75 \%$, $75-95 \%, 95-99 \%$, and $>99 \%$, respectively. In our analysis, we refer to a regressor as "effective," if its posterior inclusion probability exceeds $50 \%$. These effect thresholds are not arbitrary but based on Bayes factors that summarize the evidence provided by the data in favor of one model as opposed to another Jeffreys (1961). From Bayes factors it is 
possible to compute key quantities relevant to model uncertainty, foremost among these are the model posterior probabilities that determine the posterior inclusion probability.

Since BMA averages over all models considered, the model space may be large. For example, in this paper we consider a crisis dataset with 57 regressors which implies $2^{57}$ candidate models. Such a vast model space poses a computational challenge such that direct evaluation is not feasible. The branch-and-bound algorithm of Furnival and Wilson (1974) is guaranteed to find the single best model contained in the data. The algorithm can be refined by employing Yeung, Bumgarner, Raftery's (2005) Iterative BMA (IBMA), as we do in this application. IBMA utilizes the Unit Information Prior (Raftery, 1995) for parameters and a uniform prior for each model. Eicher, Papageorgiou and Raftery (2011) show that Unit Information Prior provides excellent predictive performance. The uniform model prior is the most commonly used prior for applications where the true model size is unknown.

\section{Dimensions of Crises and Candidate Regressors for Early Warning Signals}

\subsection{The Dataset}

The dataset used in our estimation is based on Frankel and Saravelos (2012), who collect data on all Early Warning Signals from the past 60 years of crisis indicator literature. The sources are the World Bank's World Development Indicators (World Bank, 2009), the IMF's International Financial Statistics (IMF, 2009), the updated Klein and Shambaugh (2006) measure of exchange rate regimes, and from the Chinn and Ito (2008) measure of financial openness updated to 2007. We update their dataset and fill in a host of missing variables and balance the dataset.

The highly unbalanced nature of the Frankel and Saravelos' (2012) dataset was problematic as the number of observations in their bivariate regressions ranges from 65 to 166 in the case of the FX pressure and from 25 to 65 for the case of GDP growth. Indeed none of their GDP regressions include Low Income Countries, and none of the debt or financial flow regressions include high income countries because of missing data. The original dataset is so unbalanced that Frankel and Saravelos' (2012) full model (with all possible regressors) would only feature 7 observations. When each regression has a 
distinct dataset, with a different number and different types of observations (high, medium, low income countries) it is impossible to make broad stroke inferences when any particular regressor is indeed a robust Early Warning Signal in the global sample.

Updating and balancing the dataset results in a sample of 95 countries and 57 annual macroeconomic and financial independent variables (potential Early Warning Signals) and four dependent variables (crisis indicators). All independent variables predate 2008 to minimize endogeneity issues. The data updates were at times substantial, as much of the data collection effort by Frankel and Saravelos took place during the summer of 2011, when some variables were still based on estimates and hence reported with large errors. For example, US GDP growth changes from -3.82 percent (in Frankel and Saravelos' dataset) to -5 percent for the same time period, due to successive downward revisions of US GDP by the Bureau of Economic Analysis. Such drastic revisions were common for many variables in several countries. All variables are normalized to a dimensionless standard score by subtracting the variable mean from each individual raw score and then dividing the difference by the variable's standard deviation.

Each variable in our dataset has been motivated in detail by the exhaustive survey of Frankel and Saravelos (2012); sources and definitions are presented in Appendix 1 of that paper. The dataset includes several measures covering the balance of payments, exchange rates, reserve movements, fiscal deficits, public debt, money supply, and interest rates.

\subsection{Dimensions of the Crises}

The Early Warning Signal literature commonly features a narrow set of dependent variables that are aimed to capture different dimensions of a crisis. Balance of payment crises are usually proxied with a dummy that indicates whether an IMF facility was accessed. Alternatively, variations in nominal or real exchange rates against the US dollar or SDR are used, ${ }^{3}$ and more general measures include exchange market pressure indices

\footnotetext{
${ }^{3}$ E.g., Edwards (1989); Frankel and Rose (1996); Bruggemann and Linne (1999); Osband and Rijckeghem (2000); Goldfajn and Valdes (1998); Esquivel and Larrain (1998); Apoteker and Barthelemy (2000); Rose and Spiegel (2009, 2010); Giannone, Lenza and Reichlin (2011); Dwyer and Tan (2014).
} 
which combine exchange rates, reserves, and/or interest rates. ${ }^{4}$ Banking crises have been identified using a range of regressors that reflect the health of the financial system, such as liquidity or leverage ratios..$^{5}$ Equity and output contractions are straightforwardly proxied with changes in GDP or stock prices. ${ }^{6}$

Considering various crisis dimensions is particularly important for our analysis as the 2008 Crisis affected countries through different channels and manifested itself in different types of crisis. Below we examine which of the established Early Warning Signals identify countries that experienced larger output contractions, more severe balance of payments crises, banking crises, or required IMF support as lender of last resort. While some approaches use these Early Warning Signals in conjunction with thresholds, ${ }^{7}$ we focus on continuous measures that produce results that are insensitive to particular researcher-specified crisis-threshold definitions. IMF support is the one discrete (zero-one) dependent variable.

\subsection{Candidate Regressors for Early Warning Signals}

The theoretical and empirical literature on economic crises has been succinctly summarized by Frankel and Saravelos (2012) in the most expansive survey to date. They survey 83 empirical approaches and motivate each potential Early Warning Signal that we employ below. Since the Frankel and Saravelos data is detailed in their paper, we provide only a short overview of the key areas that motivate the specific Early Warning Signals that are included in our dataset. The multitude of candidate theories and

\footnotetext{
${ }^{4}$ E.g., Sachs, Tornell and Velasco (1996a,b); Corsetti, Pesenti and Roubini (1998); Fratzcher (1998); Kaminsky, Lizondo and Reinhart (1998); Berg and Pattillo (1999a,b); Tornell (1999); Bussiere and Mulder (1999, 2000); Collins (2003); and Frankel and Wei (2005), Eichengreen, Rose and Wyplosz (1995); Herrera and Garcia (1999); Hawkins and Klau (2000); Krkoska (2001); Frankel and Saravelos (2012), Bussiere (2013), Babecký et al (2014), and Bussiere and Fratzscher (2006).

${ }^{5}$ Demirguc-Kunt and Detragiache (2005); Davis and Karim (2008); Kaminsky and Reinhart (1999); Borio and Lowe (2002); Borio and Drehmann (2009); Duttagupta and Cashin (2008); Karim (2008); Davis and Karim (2008); and Barrell.

${ }^{6}$ For example, Ghosh and Ghosh (2003); and Grier and Grier (2001).

${ }^{7}$ E.g., Frankel and Rose (1996) define "currency crashes" as a $20 \%$ nominal exchange rate depreciation that also exceeds the previous year's depreciation by least 10\%; while Eichengreen, Rose and Wyplosz (1995), define "exchange market crises" as two standard deviation movements of a speculative pressure index.
} 
regressors highlight the associated model uncertainty. The regressors cover 3 broad categories: external imbalances; institutions; and size, income, and income/GDP growth.

Krugman's (1979) seminal paper on balance of payments crises provided the impetus for a voluminous literature that focuses on weak economic fundamentals, for example, unsustainable fiscal or monetary policies. Such policies then result in unsustainable losses in reserves accompanied by excessive growth in domestic credit. The credit growth could also indicate a need to finance excessive fiscal deficits or debt imbalances. Extensions of Krugman's framework suggest that unsustainable fiscal and monetary policies can also lead to excessive demand for traded goods, causing deteriorations in the trade balance and real appreciations to foreshadow balance of payments crises.

Theories relating to domestic and international debt crises focus on a country's regulatory policies and on the determinants of fragility in the banking system (see De Gregorio, 2009). For banking crises, Cecchetti (2008) highlights the importance of the composition of banks' balance sheets when foreign or domestic funds dry up due to contagion, country risk, or global crisis. Demirguc-Kunt and Detragiache (1998) suggest banking crises may also be caused by macroeconomic variables such as slow real GDP growth, terms of trade deteriorations, and domestic real credit growth. All of these factors are thought to undermine economic fundamentals to negatively impact bank liquidity. To proxy for these effects we also include seven measures of credit growth, the quality of credit information, and banking fragility.

Acemoglu, et al. (2003) also document that weaknesses in countries' general institutional environments can increase macroeconomic volatility. To control for institutional differences, we include 3 indices that address the quality of countries' legal frameworks, their openness to capital flows, and their quality of disclosure in business and financial transactions. Montiel and Reinhart (1999) argue that openness to capital flows is especially important in liquidity crises. While openness can assist foreign borrowing necessary to finance domestic bottlenecks, it can also lead to excessive capital flow reversals when hot money exits a country due to, for example, contagion. For example, Diaz and Alejandro (1985) and Velasco (1987) model difficulties in the banking sector as giving rise to balance of payments crises. They argue that central bank 
bail-outs of troubled financial institutions could be financed by printed money, causing a currency crash prompted by excessive money creation.

Several theories of economic crises suggest country size and income levels as important determinants. Smaller countries can experience exceptional growth, capital inflows, or credit expansion relative to the size of their financial sectors or GDPs. Size also correlates with openness, as smaller countries are usually more open (as suggested by optimal tariff arguments) and thus relatively more exposed to fluctuations in world trade. In addition, smaller countries lack the ability to provide extensive government assistance in times of crisis, see (e.g. Reinhart and Reinhart, 2009). Calomiris and Gorton (1991) point out those recessions can precede banking crises, especially when output contractions follow periods of high credit growth. Hence we include 5 different measures of GDP, per capita GDP, as well as credit growth to proxy for these theories.

\section{Empirical Support for Early Warning Signals}

We examine Early Warning Signals for 4 different dimensions of the 2008 crisis a) banking crises, b) balance of payments crises, c) recessions, and d) exchange rate crises. As outlined in the previous section, all candidate Early Warning Signals employed have been motivated by past theoretical approaches and empirical implementations. These variables have been included and motivated by Frankel and Saravelos (2012). Frankel and Saravelos (2012) also employ additional Early Warning Signals that relate to debt performance. Since debt data would limit the subsample of low income and developing countries, we do not explore the analysis here.

Our indicator for banking crises is the ratio of banks' liquid reserves to assets from the World Development Indicators, where less liquidity is thought to indicate greater crisis potential. Balance of payments crises are identified by IMF programs under Stand-By, Exogenous Shock, and/or Poverty Reduction and Growth facilities. GDP contractions are proxied by the real 2009 growth rate. Exchange rate crises are given by the Frankel and Saravelos' Foreign Exchange Market Pressure Index from August 2008 to March 2009, which measures combined changes in exchange rates and international reserves. Following Eichengreen, Rose and Wyplosz (1995), the index is a weighted 
average of exchange rate and reserve changes, where the weights are the inverse of the relative standard deviations of each series, to compensate for differences in volatilities.

\subsection{Early Warning Signals for Balance of Payments Crises}

The incidence of balance of payment crises is proxied by country access to IMF programs. This measure indicates not only the incidence of a crisis, but also whether a country requested access and received IMF approval. The advantage of this indicator is that it measures balance of payment crises narrowly, since IMF Articles of Agreement require justification in terms of adverse developments in the balance of payments. Strictly speaking, a country facing a pure debt or banking crisis should not access IMF financing. Since there exist potentially significant time lags between crisis incidence and IMF program approval, we included all programs approved through 2011. Coverage of the global sample is important for this indicator, since the recent crisis produced programs for advanced countries that had not accessed IMF credit for decades.

BMA identifies three Early Warning Signals for balance of payments crisis: high inflation, low reserves, and trade deficits are shown to predict the incidence of IMF programs during the 2008 crisis. All of these are key variables of macroeconomic imbalances and external weakness that tend to be a focus of IMF programs, so their presence is not surprising. Surprising is perhaps how parsimonious is the set of regressors that predict balance of payment crises.

\subsection{Early Warning Signals of Recessions}

The regressions linking real GDP contractions to Early Warning Signals clearly highlight that the most dramatic output contractions occurred in high income countries. BMA results indicate that high income countries were more likely to have dramatic output contractions. Note that we are following the Frankel and Saravelos (2012) convention where the dependent variable indicates higher growth rates, rather than greater recessions. Crucial in determining the magnitude of the recessions was also the size of the current account deficit in 2007, with a higher surplus associated with smaller contractions, as well as the change in the current account surplus in the previous 5 years, 
with a larger rise associated with larger contractions. The former is easier to interpret than the latter. A sustained increase in surpluses may be indicative of a rising dependence on international credit, which came to a near-stop as a result of the crisis, which saw drastic reductions in the volume of trade. Therefore, the trade credit collapse exerted a greater impact on countries that had recently relied more heavily on export growth in the recent past. On the other hand, a stronger current account balance just prior to the crisis may be indicative of smaller pre-crisis macroeconomic imbalances, which by itself was a protective factor against contractions.

Along with the external balance, the rise in domestic credit in the 5 years preceding the crisis is also identified as a crucial determinant of the magnitude of recession. The results suggest that a greater run up in credit generates more severe recessions. This is in line with conventional understanding, that rapid credit was related either to asset (especially real estate) bubbles, or a general loss of macroeconomic control. Once the crisis arrived, those countries with more egregious run-ups, paid a higher price in terms of lost output. A marginally important regressor is net balance of payments income. A higher income is shown to exert a weak effect on predicting recessions (meaning worse recessions on average). This may indicate that some countries' dependence on such income proved detrimental as the crisis hit trade related finance particularly hard.

Note that so far there is little overlap between determinants of recessions and those predicting IMF programs, suggesting little hope of finding a "robust" Early Warning Signal, one that predicts all different types of economic crises.

\subsection{Early Warning Signals of Exchange Rate Crises}

The exchange rate crisis indicator was constructed by Frankel and Saravelos (2012) for August 2008 to March 2009 following the Eichengreen, Rose and Wyplosz (1995) methodology. To capture crises in both fixed and flexible regimes and taking into account that IMF programs (where present) provide additional reserves in times of crisis, the FX pressure index measures the weighted average of the change in the exchange rate and reserves. The weights are determined by (the inverse) relative standard deviations of each 
series in order to compensate for differences in volatilities. A higher index captures a lower crisis incidence, since it indicates a stronger exchange rate and/or larger reserve accumulations.

As expected, a number of candidate regressors straightforwardly related to the external sector have strong influence on FX pressure. An appreciating real effective exchange rate (measured over the prior 5 years, which thus captures a sustained loss of competitiveness), lower remittances, and larger trade deficits all increase FX pressure. More interesting is the finding that lower bank liquidity-to-asset ratios also increase FX pressure, as do lower levels of domestic credit. The former may have a straightforward interpretation, as it links banking system weakness (lack of liquidity) with problems in the FX market. The latter, however, may be indicative simply of the level of financial sophistication and development, which can thus be seen to provide some protection against FX pressures, other things equal.

Of secondary importance, exerting weak to moderate effects on FX pressure, are higher rates of GDP deflator, linked to higher FX pressures, and per capita GDP. The latter indicates once again that richer countries were those primarily impacted by the FX crisis. Note that there is little overlap between the specific Early Warning Signals that predict FX pressure and those that predict other dimensions of crises (one signal only for each of the other types of crises).

\subsection{Early Warning Signals of Banking Crises}

Certainly the start of the 2008 crisis is closely related to the failures of the investment houses of Bear Sterns and Lehman Brothers. The questionable values of US toxic housing assets became quickly apparent, which reduced interbank market liquidity and credibility. Frankel and Saravelos (2012) suggest the key indicator that relates to banking crises: a country's bank liquid reserves to bank assets ratio. The indicator reports the ratio of domestic currency holdings and deposits with the monetary authorities to claims on other governments, nonfinancial public enterprises, the private sector, and other banking institutions as reported by the World Development Indicators. A lower liquidity to asset indicator is thought to reflect higher risk of banking crisis. 
BMA reports the largest set of Early Warning Signals for the bank liquidity ratio with 9 effective regressors. Four Early Warning Signals are weakly effective, while two are decisive. The risk of a banking crisis was clearly elevated in high income countries (as measured by high per capita GDP, and by high and low income variables). ${ }^{8}$ Trade variables seem to go in opposite directions at first glance, with exports of services being protective against bank crises, and with exports of goods being actually linked with more severe banking problems. The likely explanation is similar to that noted for the case of recessions. With the collapse of trade credit, countries that relied heavily on goods exports were at greater risk of banking crises, while relatively larger service exports as a per cent of GDP insulated countries from banking crises. Service exports traditionally do not rely on trade finance (such as that provided by Export-Import banks), and hence were relatively insulated from the impact of the collapse in trade credit. Finally, and perhaps not surprisingly, lack of financial openness is associated with a greater risk of a banking crisis, indicating a relative lack of alternative and diversified options to react to shocks.

One other initially puzzling result from the BMA estimation suggests that higher rates of inflation in the 5 years prior to 2008 are associated with a lower risk of banking crisis, whereas higher CPI inflation in 2007 was associated with a higher risk of banking crisis (in the sense that higher inflation produced higher liquidity to asset ratios). This may be an artifact of basic banking principles, where higher sustained rates of inflation reduce incentives to lend, leading to a relative reduction of illiquid assets, which artificially inflates the ratio of liquid to non liquid assets. With fewer funds committed to rather illiquid investments, to minimize the impact of high inflation, banks are better prepared for liquidity crises. Of course, sustained higher rates of inflation can also help conceal problematic loans, which were better able to be serviced simply because of higher prices made possible by the rise in overall prices. The pre-crisis inflation rate, on the other hand, by itself, provides an indication of the size of macroeconomic imbalances which, again, seems linked with more severe banking crises.

\footnotetext{
${ }^{8}$ The Sub-Saharan Africa area dummy goes the "wrong" way in that it indicates a worse banking crisis, other things equal. However, the size of the posterior mean is lower than that the variable capturing GDP per capita, so what this says is that being a poor country located in Sub-Saharan Africa was still beneficial (less strong banking crisis), but less beneficial than being an equally poor country located elsewhere.
} 


\subsection{Robustness}

The previous analysis elicited Early Warning Signals for a global sample of countries. Our baseline results may be sensitive to alternative country groupings based on income or to different prior specifications.

Since the crisis emanated from high income countries, Table 2 reports Early Warning Signals when dummy interactions for high-income countries are included. Financial openness remains an important Early Warning Signal and financially closed countries are shown to feature less liquid banking sectors. In addition, the net income component of the balance of payments is shown to have a statistically negative effect on bank liquidity in high-income countries but a positive effect for the rest of the sample. Also, Middle East and North Africa regional dummies exhibit a positive effect on bank liquidity. Even with upper-income level interactions, Early Warning Signals for exchange rate pressure are similar to results in Table 1. In addition to the results in Table 1, the interaction approach reveals that high-income countries had decreased FX Pressure when they experienced greater investment, lower interest rates, and lower inflation in 2007. This is consistent with the flight to safety and especially the appreciation of the dollar observed during the Global Financial Crisis.

For GDP growth, we find that high-income countries with higher debt had lower growth than the rest of the sample, but otherwise the results from Table 1 are broadly confirmed. Some marginally effective variables turn ineffective once interactions are introduced. (e.g., BOP net income payments and the domestic credit). In general, the interaction results do not reveal any new Early Warning Signals for credit, growth, and banking crises. IMF programs are not relevant to our inquiry into high-income dummy interactions given the time period that we cover.

Next we consider whether alternative priors affect our baseline results. With 93 observations and 54 regressors it would be surprising to find results invariant to prior specifications; the dearth of data (or information) renders it more difficult to overcome strong priors. Fernandez, Ley and Steel (2001b) developed benchmark priors for Bayesian Model Averaging and Eicher, Papageorgiou, Raftery (2011) examined the predictive performance of these priors in the context of growth regressions. Both papers 
note that prior densities should be sufficiently spread out to cover the region of the parameter space where the likelihood is substantial, but not more spread out than necessary. Whether this is indeed the case here can be assessed through predictive performance, which is however beyond the scope of this paper. Here we simply highlight effects of alternative priors.

Priors vary by the penalty they assign to less parsimonious models and the effect of the penalty is mirrored in our results. In the case of economic growth, priors 3, 6, 9, 12 suggested by Fernandez Ley and Steel (2001b) all produce similar results as our baseline prior. In contrast, priors $2,4,5$, and 7 feature much smaller penalties and hence suggest greater numbers of potential Early Warning Signals. ${ }^{9}$ In just about every case, however, these additional signals barely surpass the minimum effect threshold.

For credit crises, the prior sensitivity analysis exhibits a similar pattern. Results are just about identical to those in Table 1, except for priors 5 and 7 that again suggest substantially greater numbers of Early Warning Signals (because of their substantially smaller penalties for less parsimonious models). ${ }^{10}$ Previous analyses by Fernandez, Ley and Steel (2001b) and Eicher, Papageorgiou, Raftery (2011) indicate, however, that these two priors do not generate good predictive performance hence we caution against the interpretation that these additional signals serve as effective Early Warning Signals.

\section{Conclusion}

We examine whether the consensus Early Warning Signals suggested by the voluminous crisis literature could have predict the 2008 crisis. To do so, we use the latest dataset available and introduce recent advances in the empirical methodology. First, we updated the comprehensive dataset constructed by Frankel and Saravelos (2012) by incorporating crucial data revisions from national accounts, World Bank, and IMF data. In addition, we balance our dataset in that each regression covers the same sample of countries. Second,

\footnotetext{
9 They include credit_domestic_pctgdp_5yr_rise, gdpdeflator_pct_annual, creditdepthofinfo, m2growth_pct, remittancesreceived_pct_gdp, mena, fdicurrentusd, tradebalance_pct_gdp, ca_pct_gdp, govexp_pct_gdp, incomenetbopusd, fdiinflows_pct_gdp, domesticcredittotal_pct_gdp.

10 credit_domestic_pctgdp_5yr_rise, gdpdeflator_pct_annual, creditdepthofinfo, m2growth_pct, remittancesreceived_pct_gdp, mena, fdicurrentusd, tradebalance_pct_gdp, ca_pct_gdp, govexp_pct_gdp

Incomenetbopusd, fdiinflows_pct_gdp.
} 
we employ this dataset in Bayesian Model Averaging, a methodology designed to address the omitted variable bias and model uncertainty existent in previous approaches.

In contrast to the earlier 2008-crisis literature, which stipulated that none of the established Early Warning Signals existed for this particular crisis, it is shown that four different dimensions of the 2008 crisis - Banking, Balance of Payments, Exchange Rate Pressure, and Recession - are well identified by distinct sets of Early Warning Signals. This is important because it provides credence to the 60 year old literature that had been called into question when a number of studies did not find any effective indicators to alert countries of impending economic crises. This is primarily because BMA discovered and made use of better models than the single frequentist regressions run by the existing literature. The models that are shown to receive the greatest support from the data identify Early Warning Signals with highest effectiveness.

In contrast to the Frankel and Saravelos (2012) results, we cannot confirm a single set of Early Warning Signals that could have alerted countries to all dimensions of the 2008 crisis. Our results differ from Frankel and Saravelos for two reasons. First, Frankel and Saravelos rely on bivariate regressions that are subject to significant model uncertainty and omitted variable bias. Frankel and Saravelos effectively stipulate that each of their bi-variate regression is the true model, without a mechanism to juxtapose the performance of alternative models and theories. Second, Frankel and Saravelos regressions contain different subsamples of countries in each regression. This could imply that each Early Warning Signal actually alerts to crises in different subsets of countries. Once model uncertainty is addressed and the dataset is balanced, different sets of Early Warning Signals identify each dimension of the 2008 crisis in the global sample. The main policy message emerging from this analysis is that the nature of the impending crisis needs to be specified before Early Warning Signals are examined, since they are crisis-specific. 


\section{REFERENCES}

Abiad, A., 2003. "Early Warning Systems: A Survey and a Regime-Switching Approach," IMF Working Papers 03/32, International Monetary Fund.

Acemoglu, D., S. Johnson, J. Robinson and Y. Thaicharoen, 2003. "Institutional Causes, Macroeconomic Symptoms: Volatility, Crises and Growth," Journal of Monetary Economics, vol. 50(1), 49-123.

Apoteker, T., and S. Barthelemy, 2000. "Genetic Algorithms and Financial Crises in Emerging Markets, "AFFI International Conference in Finance Processing.

Babecký, Jan \& Havránek, Tomáš \& Matějů, Jakub \& Rusnák, Marek \& Šmídková, Kateřina \& Vašíček, Bořek, 2014. "Banking, debt, and currency crises in developed countries: Stylized facts and early warning indicators," Journal of Financial Stability, 15, 1-17.

Berg, A., and C. Pattillo, 1999a. "Are Currency Crises Predictable? A Test," IMF Staff Papers, vol. 46(2), 107-138.

Berg, A., and C. Pattillo, 1999b. "Predicting Currency Crises: The Indicators Approach and an Alternative," Journal of International Money and Finance, vol. 18(4), 561586.

Berg, A., E. Borensztein, and C. Pattillo, 2005, "Assessing Early Warning Systems: How Have They Worked in Practice?" IMF Staff Papers, vol. 52(3), 462-502.

Blanchard, O., H. Faruqee, and V. Klyuev, 2009. "Did Foreign Reserves Help Weather the Crisis," IMF Survey Magazine, IMF, Oct. $8^{\text {th }}$.

Bussiere, M., and C. Mulder, 1999. "External Vulnerability in Emerging Market Economies - How High Liquidity Can Offset Weak Fundamentals and the Effects of Contagion," IMF Working Papers 99/88, International Monetary Fund. 46

Bussiere, M., and C. Mulder, 2000. "Political Instability and Economic Vulnerability," International Journal of Finance \& Economics, vol. 5(4), 309-330.

Bussiere, M. 2013. Balance of Payment Crises in Emerging Markets: How Early Were the 'Early' Warning Signals? Applied Economics, 459(12), 1601-1623.

Bussiere, M. and Fratzscher, M. 2006. Towards a New Early Warning System of Financial Crises. Journal of International Money and Finance, 25(6), 953-973.

Chinn, M, and H. Ito, 2008. "A New Measure of Financial Openness," Journal of Comparative Policy Analysis 10(3), 309-22. Data for Chinn-Ito financial openness measure extending to 2007, updated February 2009 downloaded from: http://www.ssc.wisc.edu/ mchinn/research.html

Collins, S., 2003. Probabilities, Probits and the Timing of Currency Crises, Georgetown University, The Brookings Institution and NBER.

Corsetti, G., P. Pesenti and N. Roubini, 1998. "Paper Tigers? A Model of the Asian Crisis," Research Paper 9822, Federal Reserve Bank of New York. 
Davis, E.P., and D. Karim, 2008. "Comparing Early Warning Systems for Banking Crises," Journal of Financial Stability, vol. 4(2), 89-120.

Demirguc-Kunt, A., and E. Detragiache, 2005. "Cross-country Empirical Studies of Systemic Bank Distress: A Survey," Policy Research Working Paper Series 3719, World Bank.

Demirgüç-Kunt, A. and E. Detragiache, 1998, "The Determinants of Banking Crises: Evidence from Developing and Developed countries," IMF Staff Papers, vol. 45, 81-109.

Dwyer, S. and C.M. Tan, 2014, "Hits and Runs: Determinants of the Cross-Country Variation in the Severity of Impact from the 2008-9 Financial Crisis," Journal of Macroeconomics, vol. 42, 69-90.

Edwards, S., 1989. Real Exchange Rates, Devaluation, and Adjustment: Exchange Rate Policy in Developing Countries (MIT Press Cambridge, MA).

Eichengreen, B., A. Rose, and C. Wypslosz, 1995. "Exchange Market Mayhem: The Antecedents and Aftermath of Speculative Attacks," Economic Policy, vol.10, 249-312.

Eicher T.S., C. Papageorgiou, and A.E. Raftery, 2011. "Default Priors and Predictive Performance in Bayesian Model Averaging, with Application to Growth Determinants," Journal of Applied Econometrics, vol. 26, 30-55.

Fernandez C., E. Ley and M. Steel, 2001. "Model Uncertainty in Cross-country Growth Regressions," Journal of Applied Econometrics, vol. 16, 563-576.

Fernandez C., E. Ley and M. Steel, 2001b. "Benchmark priors for Bayesian Model Averaging, Journal of Econometrics, 100 (2), 381-427

Frankel, J., and A. Rose, 1996. "Currency Crashes in Emerging Markets: An Empirical Treatment," Journal of International Economics vol. 41, 351-366.

Frankel, J., and S.-J. Wei, 2005. "Managing Macroeconomic Crises," Chapter 7, in Managing Economic Volatility and Crises: A Practitioner's Guide, edited by Joshua Aizenman and Brian Pinto (Cambridge University Press).

Frankel, J., and G. Saravelos, 2012. "Can Leading Indicators Assess Country Vulnerability? Evidence from the 2008-09 Global Financial Crisis," Journal of International Economics, vol. 87, 216-231.

Frankel, J., and G. Saravelos, 2010. "Can Leading Indicators Assess Country Vulnerability? Evidence from the 2008-09 Global Financial Crisis," NBER Working Paper 16047.

Ghosh, S.R., and A.R. Ghosh, 2003. "Structural Vulnerabilities and Currency Crises," IMF Staff Papers, vol. 50, 481-504.

Giannone, D., M. Lenza and L. Reichlin, 2011. "Market Freedom and the Global Recession," IMF Economic Review, vol. 59, 111-135.

Goldfajn, I., and R.O. Valdes, 1998. "Are Currency Crises Predictable?" European Economic Review, vol. 42, 873-885. 
Grier, K.B., and R.M. Grier, 2001. "Exchange Rate Regimes and the Cross-Country Distribution of the 1997 Financial Crisis," Economic Inquiry, vol. 39, 139-148.

Ho, Tai-Kuang, 2010. "Looking for a Needle in a Haystack: Revisiting the Cross-Country Causes of the 2008-09 Crisis," mimeo, National TsingHua University.

Hawkins, J., and M. Klau, 2000. "Measuring Potential Vulnerabilities in Emerging Market Economies," BIS Working Papers 91, Bank for International Settlements.

Jeffreys, H., 1961. "The Theory of Probability," Journal of the American Statistical Association, vol, 1197-1208.

Kamin, S., J. Schindler, and S. Samuel, 2001. "The Contribution of Domestic and External Factors to Emerging Market Devaluation Crises: An Early Warning Systems Approach," International Finance Discussion Papers 711, Board of Governors of the Federal Reserve System.

Kaminsky, G.L., 1999. "Currency and Banking Crises - The Early Warnings of Distress," IMF Working Papers 99/178, International Monetary Fund.

Kaminsky, G.L., S. Lizondo and C. Reinhart, 1998. "Leading Indicators of Currency Crisis," IMF Staff Papers, vol. 45, 1-41.

Kaminsky, G.L., and C. Reinhart, 1999, "The Twin Crises: Causes of Banking and Balance of Payments Problems," American Economic Review, vol. 89, 473-500.

Klein, M., and J. Shambaugh, 2006. "The Nature of Exchange Rate Regimes," NBER Working Papers 12729.

Leamer, E.E., 1978. Specification Searches: Ad Hoc Inference with Nonexperimental Data, Wiley, New York.

Nag, A., and A. Mitra, 1999. "Neural Networks and Early Warning Indicators of Currency Crisis," Reserve Bank of India Occasional Papers, vol. 20, 183-222.

Obstfeld, M., J. Shambaugh, and A. Taylor, 2009a. "Financial Instability, Reserves, and Central Bank Swap Lines in the Panic of 2008," American Economic Review, vol. 99, 480-486.

Obstfeld, M., J. Shambaugh, and A. Taylor, 2009b. "Financial Stability, the Trilemma, and International Reserves," American Economic Journal: Macroeconomics, vol. 2, 57-94.

Osband, K., and C. Rijckeghem, 2000. "Safety from Currency Crashes," IMF Staff Papers, vol. 47, 238-258.

Raftery, A.E., 1988. "Approximate Bayes Factors for Generalized Linear Models," Technical Report no. 121, Department of Statistics, University of Washington.

Raftery, A.E., 1993. "Bayesian Model Selection in Structural Equation Models," in Testing Structural Equation Models (K.A. Bollen and J.S. Long, eds.), pp. 163180, Beverly Hills: Sage.

Raftery, A.E., 1995. "Bayesian Model Selection for Social Research," Sociological Methodology, vol. 25, 111-163. 
Raftery, A.E., 1996. "Approximate Bayes Factors and Accounting for Model Uncertainty in Generalized Linear Models," Biometrika vol. 83, 251-266.

Raftery, A.E., D. Madigan and J.A. Hoeting, 1997. "Bayesian Model Averaging for Linear Regression Models," Journal of the American Statistical Association, vol. 92, 179-191.

Raftery, A.E. and Zheng, Y., 2003. Discussion: "Performance of Bayesian Model Averaging," Journal of the American Statistical Association, vol. 98, 931-938.

Rose, A., and M. Spiegel, 2009. "The Causes and Consequences of the 2008 Crisis: Early Warning," Global Journal of Economics, forthcoming. NBER Working Papers 15357.

Rose, A., and M. Spiegel, 2010. "The Causes and Consequences of the 2008 Crisis: International Linkages and American Exposure," Pacific Economic Review, vol. $15,340-363$.

Rose, A. amd M. Spiegel, 2011. "Cross-country Causes and consequences of the Crisis: An Update," European Economic Review, vol. 55, 309-324.

Sachs, J., A. Tornell, and A. Velasco, 1996a. "Financial Crises in Emerging Markets: The Lessons from 1995," Brookings Papers on Economic Activity, vol. 27, 147-216.

Sachs, J., A. Tornell, and A. Velasco, 1996b. "The Mexican Peso Crisis: Sudden Death or Death Foretold?" Journal of International Economics, vol. 41, 265-283.

Sala-i-Martin, Xavier, 1997. "I just Ran Two Million Regressions," American Economic Review, vol. 87, 178-183.

Tornell, A., 1999. "Common Fundamentals in the Tequila and Asian Crises," Harvard Institute of Economic Research Working Papers 1868, Harvard, Institute of Economic Research.

Yeung, K.Y., R.E. Bumgarner, and A.E. Raftery, 2005. "Bayesian Model Averaging: Development of an Improved Multi-Class, Gene Selection and Classification Tool for Microarray Data," Bioinformatics, vol. 21, 2394-2402.

Viallefont, V., A. Raftery, and S. Richardson, 2001. "Variable Selection and Bayesian Model Averaging in Case-Control Studies," Statistics in Medicine, vol 20, 3215 30. 
Table 1. Baseline BMA Results

\begin{tabular}{|c|c|c|c|c|c|c|c|c|c|c|c|c|}
\hline & \multicolumn{3}{|c|}{$\begin{array}{c}\text { Bank } \\
\text { Liquidity/Assets }\end{array}$} & \multicolumn{3}{|c|}{ FX Pressure } & \multicolumn{3}{|c|}{ GDP Growth } & \multicolumn{3}{|c|}{$\begin{array}{c}\text { Balance of Payments } \\
\text { Crisis }\end{array}$} \\
\hline & $\begin{array}{l}\text { Incl. } \\
\text { Prob }\end{array}$ & $\begin{array}{l}\text { Post. } \\
\text { Mean }\end{array}$ & $\begin{array}{l}\text { Post. } \\
\text { StDev }\end{array}$ & $\begin{array}{l}\text { Incl. } \\
\text { Prob }\end{array}$ & $\begin{array}{l}\text { Post. } \\
\text { Mean }\end{array}$ & $\begin{array}{l}\text { Post. } \\
\text { StDev }\end{array}$ & $\begin{array}{l}\text { Incl. } \\
\text { Prob }\end{array}$ & $\begin{array}{l}\text { Post. } \\
\text { Mean }\end{array}$ & $\begin{array}{l}\text { Post. } \\
\text { StDev }\end{array}$ & $\begin{array}{l}\text { Incl. } \\
\text { Prob }\end{array}$ & $\begin{array}{l}\text { Post. } \\
\text { Mean }\end{array}$ & $\begin{array}{l}\text { Post. } \\
\text { StDev }\end{array}$ \\
\hline Xgoodsgdp & 97 & -0.750 & 0.378 & & & & & & & & & \\
\hline cpiavlast5years & 96 & 0.382 & 0.146 & & & & & & & 100 & 1.362 & 0.466 \\
\hline sub-Saharan & 81 & -0.200 & 0.133 & & & & & & & & & \\
\hline gdppercapitapppcurrentusd & 80 & -0.470 & 0.285 & 67 & -0.292 & 0.250 & na & & na & & & \\
\hline Xgservicegdp & 74 & 0.669 & 0.503 & & & & & & & & & \\
\hline Lowincome & 58 & 0.146 & 0.146 & & & & 100 & 0.402 & 0.082 & & & \\
\hline reserves_perc_gdp_constr & 57 & 0.147 & 0.154 & & & & & & & 83 & -1.36 & 0.908 \\
\hline financiallyclosed & 54 & -0.110 & 0.124 & & & & & & & & & \\
\hline cpi2007 & 52 & -0.275 & 0.297 & & & & & & & & & \\
\hline domesticcredittotal_pct_gdp & & & & 100 & 0.568 & 0.154 & 51 & 0.170 & 0.180 & & & \\
\hline remittancesreceived_pct_gdp & & & & 100 & 0.499 & 0.131 & & & & & & \\
\hline reer5yr & & & & 100 & -0.320 & 0.092 & & & & & & \\
\hline tradebalance_pct_gdp & & & & 99 & 0.548 & 0.153 & & & & 62 & -0.805 & 0.761 \\
\hline bankliquidrestoass & na & na & na & 96 & 0.310 & 0.124 & & & & & & \\
\hline gdpdeflator_pct_annual & & & & 80 & -0.215 & 0.148 & & & & & & \\
\hline Upperincome & & & & & & & 51 & -0.147 & 0.164 & & & \\
\hline ca_pct_gdp & & & & & & & 93 & 0.641 & 0.255 & & & \\
\hline Mena & & & & & & & 100 & 0.284 & 0.084 & & & \\
\hline creditdomestic_pctgdp_5yr_rise & & & & & & & 97 & -0.294 & 0.127 & & & \\
\hline caavlast5yrs_pct_gdp & & & & & & & 100 & -0.561 & 0.187 & & & \\
\hline reserveschangesusd & & & & & & & & & & & & \\
\hline foreignassetsnetlcucurrent & & & & & & & & & & & & \\
\hline incomenetbopusd & & & & & & & 67 & -0.138 & 0.121 & & & \\
\hline Reservesusd & & & & & & & & & & 67 & -5.12 & 5.036 \\
\hline
\end{tabular}

Note: All regressors from Appendix Table 1 are included in the investigation of each crisis determinant. We only report results for candidate regressors whose inclusion probabilities exceed the effect threshold. Complete sets of results are available upon request. Banking Crisis does not include the liquidity to asset ratio as a regressor and GDP growth regressions do not include GDP related regressors. 
Table 2. BMA Results with Upper Income Interactions

\begin{tabular}{|c|c|c|c|c|c|c|c|c|c|}
\hline & \multicolumn{3}{|c|}{ Bank Liquidity/Assets } & \multicolumn{3}{|c|}{ FX Pressure } & \multicolumn{3}{|c|}{ GDP Growth } \\
\hline & $\begin{array}{l}\text { Incl. } \\
\text { Prob }\end{array}$ & $\begin{array}{l}\text { Post. } \\
\text { Mean }\end{array}$ & $\begin{array}{l}\text { Post. } \\
\text { StDev }\end{array}$ & $\begin{array}{l}\text { Incl. } \\
\text { Prob }\end{array}$ & $\begin{array}{l}\text { Post. } \\
\text { Mean }\end{array}$ & $\begin{array}{l}\text { Post. } \\
\text { StDev }\end{array}$ & $\begin{array}{l}\text { Incl. } \\
\text { Prob }\end{array}$ & $\begin{array}{l}\text { Post. } \\
\text { Mean }\end{array}$ & $\begin{array}{l}\text { Post. } \\
\text { StDev }\end{array}$ \\
\hline reer5yr & 98 & 0.351 & 0.103 & 100 & -0.318 & 0.102 & & & \\
\hline Financiallyclosed & 97 & -0.252 & 0.095 & & & & & & \\
\hline Incomenetbopusd & 96 & 1.032 & 0.355 & & & & & & \\
\hline UpIncome*incomenetbopusd & 96 & -0.943 & 0.339 & & & & & & \\
\hline Mena & 89 & 0.193 & 0.100 & & & & 91 & 0.207 & 0.101 \\
\hline domesticcredittotal_pct_gdp & & & & 100 & 0.663 & 0.139 & & & \\
\hline remittancesreceived_pct_gdp & & & & 100 & 0.460 & 0.116 & & & \\
\hline UpIncome*investment_pct_gdp & & & & 100 & 1.077 & 0.453 & & & \\
\hline gdppercapitapppcurrentusd & & & & 99 & -0.610 & 0.189 & na & na & na \\
\hline Bankliquidrestoass & na & na & na & 97 & 0.270 & 0.111 & & & \\
\hline tradebalance_pct_gdp & & & & 97 & 0.569 & 0.182 & & & \\
\hline UpIncome* realintrate & & & & 65 & -0.136 & 0.123 & & & \\
\hline UpIncome*cpi2007 & & & & 63 & -0.297 & 0.259 & & & \\
\hline ca_pct_gdp & & & & & & & 100 & 0.736 & 0.192 \\
\hline Lowincome & & & & & & & 100 & 0.366 & 0.074 \\
\hline Publicdebtgdp & & & & & & & 100 & 0.407 & 0.115 \\
\hline UpIncome*publicdebtgdp & & & & & & & 100 & -0.456 & 0.115 \\
\hline caavlast5yrs_pct_gdp & & & & & & & 96 & -0.487 & 0.197 \\
\hline Eapacific & & & & & & & 88 & 0.177 & 0.097 \\
\hline
\end{tabular}

Notes: All regressors from Appendix Table 1 are included in the investigation of each crisis determinant. We only report results for candidate regressors whose inclusion probabilities exceed the effect threshold. Complete sets of results are available upon request. Banking Crisis does not include the liquidity to asset ratio as a regressor and GDP growth regressions do not include GDP related regressors. 


\section{Appendix 1 Table 1. Summary Statistics and Data Description}

\begin{tabular}{|c|c|c|c|c|c|}
\hline & Mean & StDev & Min & Max & Description \\
\hline fx_res_index & 0.127 & 0.171 & -0.489 & 0.515 & $\begin{array}{l}\text { Exchange market pressure from } \\
\text { August } 2008 \text { to March } 2009\end{array}$ \\
\hline imf_all & 0.269 & 0.446 & 0.000 & 1.000 & $\begin{array}{l}1 \text { if country accessed SBA, } \\
\text { PRGF or ESF from Jul } 08-\text { Dec } \\
2011\end{array}$ \\
\hline Realgdp & -1.213 & 5.4537 & -17.95 & 10.301 & $\begin{array}{l}\% \text { Change in annual real GDP } \\
2009\end{array}$ \\
\hline Bankliquidrestoass & 10.470 & 9.828 & 0.104 & 50.260 & $\begin{array}{l}\text { Bank liquid reserves to bank } \\
\text { assets ratio }(\%)\end{array}$ \\
\hline Businessdisclosure & 5.462 & 2.784 & 0.000 & 10.000 & $\begin{array}{l}\text { Business extent of disclosure } \\
\text { index }(0=\text { less disclosure to } \\
10=\text { more })\end{array}$ \\
\hline ca_pct_gdp & -3.099 & 10.730 & -28.920 & 27.290 & $\begin{array}{l}\text { Current account balance (\% of } \\
\text { GDP) }\end{array}$ \\
\hline ca2007_pct_gdp & -3.099 & 10.730 & -28.920 & 27.290 & CA2007\%GDP \\
\hline caavlast5yrs_pct_gdp & -2.053 & 7.982 & -23.820 & 22.980 & CAAvLast5Yrs\%GDP \\
\hline consumption_pct_gdp & 79.800 & 14.660 & 40.270 & 119.200 & $\begin{array}{l}\text { Final consumption expenditure, } \\
\text { etc. }(\% \text { of GDP) }\end{array}$ \\
\hline срі2007 & 5.902 & 3.633 & 0.058 & 16.690 & CPI2007 \\
\hline cpiavlast5years & 5.847 & 5.177 & -0.046 & 38.060 & CPIAvLast5Years \\
\hline credit_domestic_pct_gdp & 0.753 & 0.560 & -0.164 & 2.127 & Domestic Credit \% of GDP \\
\hline credit_domestic_pctgdp_5yr_rise & 0.083 & 0.257 & -0.758 & 0.920 & $\begin{array}{l}\text { Domestic Credit \% of GDP 5yr } \\
\text { rise }(2007-2002)\end{array}$ \\
\hline Creditdepthofinfo & 3.753 & 2.031 & 0.000 & 6.000 & $\begin{array}{l}\text { Credit depth of information } \\
\text { index }(0=\text { low to } 6=\text { high })\end{array}$ \\
\hline Currenttransfersreceiptsusd & $6 . \mathrm{E}+09$ & 8.E+09 & $0 . \mathrm{E}+00$ & 4. $\mathrm{E}+10$ & $\begin{array}{l}\text { Current transfers, receipts (BoP, } \\
\text { current US\$) }\end{array}$ \\
\hline Currenttransfersusd & $-2 . E+09$ & 1. $\mathrm{E}+10$ & $-1 . E+11$ & 4. $E+10$ & $\begin{array}{l}\text { Net current transfers (BoP, } \\
\text { current US\$) }\end{array}$ \\
\hline domesticcreditbybanks_pct_gdp & 80.120 & 62.250 & -16.370 & 294.200 & $\begin{array}{l}\text { Domestic credit provided by } \\
\text { banking sector ( } \% \text { of GDP) }\end{array}$ \\
\hline Domesticcreditlcu & $6 . \mathrm{E}+13$ & 2. $\mathrm{E}+14$ & $-1 . \mathrm{E}+10$ & 2.E+15 & $\begin{array}{l}\text { Net domestic credit (current } \\
\text { LCU) }\end{array}$ \\
\hline domesticcredittotal_pct_gdp & 70.460 & 54.620 & 8.183 & 210.100 & $\begin{array}{l}\text { Domestic credit to private sector } \\
(\% \text { of GDP) }\end{array}$ \\
\hline Eapacific & 0.129 & 0.337 & 0.000 & 1.000 & EA\&Pacific \\
\hline Euroarea & 0.140 & 0.349 & 0.000 & 1.000 & EuroArea \\
\hline Fdicurrentusd & $-1 . E+09$ & 3. $\mathrm{E}+10$ & $-1 . E+11$ & 1.E+11 & $\begin{array}{l}\text { Foreign direct investment, net } \\
\text { (BoP, current US\$) }\end{array}$ \\
\hline fdiinflows_pct_gdp & 10.440 & 39.280 & -14.370 & 380.300 & $\begin{array}{l}\text { Foreign direct investment, net } \\
\text { inflows ( } \% \text { of GDP) }\end{array}$ \\
\hline Fdiinflowsusd & 2.E+10 & $5 . \mathrm{E}+10$ & $-8 . E+09$ & 2.E+11 & $\begin{array}{l}\text { Foreign direct investment, net } \\
\text { inflows (BoP, current US\$) }\end{array}$ \\
\hline Financiallyclosed & 0.204 & 0.405 & 0.000 & 1.000 & $\begin{array}{l}1 \text { if in bottom } 30 \text { pctile in Chinn } \\
\text { \& Ito (2008) financial openness } \\
\text { index }\end{array}$ \\
\hline Foreignassetsnetlcucurrent & 1.E+13 & 7.E+13 & $-3 . E+11$ & $5 . \mathrm{E}+14$ & Net foreign assets (current LCU) \\
\hline Gdpdeflator & 1.E+03 & 1. $\mathrm{E}+04$ & 9. $\mathrm{E}+01$ & 1.E+05 & $\begin{array}{l}\text { GDP deflator (base year varies } \\
\text { by country) }\end{array}$ \\
\hline gdpdeflator_pct_annual & 6.901 & 5.242 & -3.833 & 22.750 & $\begin{array}{l}\text { Inflation, GDP deflator (annual } \\
\% \text { ) }\end{array}$ \\
\hline gdpgrowth2007 & 5.943 & 3.745 & -2.129 & 25.050 & GDPgrowth 2007 \\
\hline gdpgrowthlast5yrs & 5.423 & 3.152 & -0.887 & 21.470 & $\begin{array}{l}\text { Average GDP growth last } 5 \\
\text { years }\end{array}$ \\
\hline Gdppercapitagrowth & 4.856 & 3.803 & -2.107 & 23.640 & $\begin{array}{l}\text { GDP per capita growth (annual } \\
\%)\end{array}$ \\
\hline Gdppercapitapppcurrentusd & 2.E+04 & 1.E+04 & 8. $\mathrm{E}+02$ & 8.E+04 & $\begin{array}{l}\text { GDP per capita, PPP (current } \\
\text { international \$) }\end{array}$ \\
\hline
\end{tabular}




\begin{tabular}{|c|c|c|c|c|c|}
\hline \multicolumn{6}{|l|}{ Appendix Table 1 (continued) } \\
\hline & Mean & StDev & Min & Max & Description \\
\hline Gdppppcurrentusd & $6 . \mathrm{E}+11$ & 2.E+12 & 4. $\mathrm{E}+08$ & 1.E+13 & $\begin{array}{l}\text { GDP, PPP (current international } \\
\$ \text { ) }\end{array}$ \\
\hline govexp_pct_gdp & 18.330 & 8.356 & 3.364 & 42.500 & $\begin{array}{l}\text { General government final } \\
\text { consumption expenditure ( } \% \text { of } \\
\text { GDP) }\end{array}$ \\
\hline Incomenetbopusd & $-3 . E+08$ & 2. $E+10$ & $-4 . E+10$ & 1. $\mathrm{E}+11$ & Net income (BoP, current US\$) \\
\hline investment_pct_gdp & 25.010 & 6.271 & 12.970 & 43.300 & $\begin{array}{l}\text { Gross capital formation ( } \% \text { of } \\
\text { GDP) }\end{array}$ \\
\hline Latamcarribean & 0.183 & 0.389 & 0.000 & 1.000 & LatAm\&Carribean \\
\hline Legalrightsindex & 5.892 & 2.420 & 0.000 & 10.000 & $\begin{array}{l}\text { Strength of legal rights index } \\
(0=\text { weak to } 10=\text { strong })\end{array}$ \\
\hline Lowincome & 0.129 & 0.337 & 0.000 & 1.000 & LowIncome \\
\hline m2_pct_gdp & 86.070 & 143.300 & 16.150 & 1349.000 & $\begin{array}{l}\text { Money and quasi money (M2) } \\
\text { as \% of GDP }\end{array}$ \\
\hline m2growth_pct_ & 18.700 & 13.930 & -25.340 & 73.210 & $\begin{array}{l}\text { Money and quasi money growth } \\
\text { (annual \%) }\end{array}$ \\
\hline m2lcu_100mil & 5.E+05 & 2.E+06 & 3. $\mathrm{E}+00$ & 2. $\mathrm{E}+07$ & $\begin{array}{l}\text { Money and quasi money (M2) } \\
\text { (100 bil LCU) }\end{array}$ \\
\hline Mena & 0.086 & 0.282 & 0.000 & 1.000 & ME\&NA \\
\hline merchandisetrade_pct_gdp & 81.960 & 51.830 & 21.540 & 347.500 & Merchandise trade ( $\%$ of GDP) \\
\hline Mgoodsgdp & -42.200 & 25.350 & -176.600 & -8.752 & Imports Goods (\% of GDP) \\
\hline Mgservicegdp & -52.330 & 31.040 & -197.100 & 0.000 & $\begin{array}{l}\text { Imports Goods and Services (\% } \\
\text { of GDP) }\end{array}$ \\
\hline Northamerica & 0.022 & 0.146 & 0.000 & 1.000 & NorthAmerica \\
\hline Portfolioinvequityusd & 7.E+09 & 4. $E+10$ & $-1 . E+11$ & 3. $\mathrm{E}+11$ & $\begin{array}{l}\text { Portfolio investment, equity } \\
\text { (DRS, current US\$) }\end{array}$ \\
\hline Publicdebtgdp & 44.520 & 32.510 & 3.742 & 187.700 & Public Debt (\% of GDP) \\
\hline Realintrate & 0.165 & 3.641 & -9.811 & 13.800 & Real Interest Rate (\%) \\
\hline reer5yr & 107.200 & 18.080 & 68.900 & 170.500 & $\begin{array}{l}\text { REER5yr_pct_rise }(+= \\
\text { appreciation) }\end{array}$ \\
\hline reerdev10yravg & 104.700 & 16.470 & 62.390 & 153.900 & REERDevFrom $10 \mathrm{yrAv}$ \\
\hline remittancesreceived_pct_gdp & 4.933 & 7.482 & 0.000 & 39.370 & $\begin{array}{l}\text { Workers' remittances and } \\
\text { compensation, received }(\% \text { of } \\
\text { GDP) }\end{array}$ \\
\hline reserves_perc_gdp_constr & 0.200 & 0.174 & 0.004 & 0.976 & $\begin{array}{l}\text { Foreign Exchange Reserves ( } \% \\
\text { of GDP) }\end{array}$ \\
\hline Reserveschangesusd & $-6 . E+09$ & $6 . E+10$ & $-5 . E+11$ & 2. $\mathrm{E}+11$ & Foreign Exchange Reserves (\$) \\
\hline Reservesusd & $6 . E+10$ & 2.E+11 & 4.E+07 & 2. $\mathrm{E}+12$ & $\begin{array}{l}\text { Total reserves (includes gold, } \\
\text { current US\$) }\end{array}$ \\
\hline savings_pct_gni & 12.060 & 13.310 & -33.720 & 53.500 & Savings ( $\%$ of GNI) \\
\hline savingsdomestic_pct_gdp & 19.760 & 15.260 & -22.000 & 59.730 & $\begin{array}{l}\text { Gross domestic savings ( } \% \text { of } \\
\text { GDP) }\end{array}$ \\
\hline Southasia & 0.032 & 0.178 & 0.000 & 1.000 & SouthAsia \\
\hline sub-Saharan & 0.129 & 0.337 & 0.000 & 1.000 & Sub-Saharan \\
\hline tradebalance_pct_gdp & -5.350 & 16.420 & -52.150 & 39.620 & Trade Balance $\%$ of GDP \\
\hline Upperincome & 0.333 & 0.474 & 0.000 & 1.000 & UpperIncome \\
\hline Xgoodsgdp & 35.510 & 26.130 & 3.939 & 170.900 & Exports Goods (\% of GDP) \\
\hline Xgservicegdp & 47.860 & 33.600 & 0.000 & 218.900 & $\begin{array}{l}\text { Exports Goods and Services (\% } \\
\text { of GDP) }\end{array}$ \\
\hline
\end{tabular}

Notes: See Frankel and Saravelos (2012) for variable definitions. The summary statistics in this table are not standardized. Primary sources comprise World Bank Development Indicators, IMF International Financial Statistics, and IMF staff estimates. 


\section{Appendix 2: (Supplemental Information)}

\section{Data Descriptions}

All data definitions follow Frankel and Saravelos (2012), whenever we deviate from the FS definitions, we highlight the departure below. We use four Crisis Indicators, measured for the year 2008 as independent variables.

- $\quad$ fx_res_index is an inverse-volatility weighted average of changes in foreign exchange reserves and the exchange rate;

- GDP growth is the average annual growth rate in 2009 vs. 2008 (vs. FS who use Q2/2008-Q2/2009 which excludes all low income and many middle income countriesthe correlation between this variable and the FS variable is 0.97 ).

- Bank Liquidity/Assets is the ratio of liquid assets to total assets;

- Balance of Payments crisis is a zero-one variable capturing access to International Monetary Fund facilities, including programs through 2011, since sometimes crisis stricken-countries take some time before they are either willing or able to negotiate an IMF program.

Independent variables are generally measured pre-crisis. When the year is not indicated, it means 2007. Multi-year averages end in 2007.

- $\quad$ Current account as percent of GDP, and as a 5-year prior average as percent of GDP.

- $\quad$ Consumption as percent of GDP.

- $\quad$ CPI as percent change, and as a 5-year prior average.

- $\quad$ Current transfer receipts, and net current transfer receipts, in US dollars.

- Domestic credit, and subcomponent provided by banks, and total domestic credit to the private sector, as percent of GDP, and as 5-year prior average.

- Dummy variables for various regions (East Asia and Pacific, Euro Area, Latin America and Caribbean, Middle East and North Africa, North America, South Asia, and for SubSaharan Africa). Dummy variables for being financially closed, for the strength of legal rights, for low income, and for high income).

- $\quad$ Foreign assets, net, current (in local currency).

- $\quad$ Foreign direct investment (net inflows) in U.S. dollars.

- $\quad$ Foreign exchange reserves as percent of GDP, as U.S. dollars, and as change in their U.S. dollar value.

- $\quad$ GDP deflator index, and percent change.

- $\quad$ GDP growth, as a 5-year average, and in current U.S. PPP dollars.

- $\quad$ GDP per capita growth in percent, and in current U.S. PPP dollars.

- $\quad$ Net balance of payments income, in current U.S. dollars.

- Investment as percent of GDP.

- $\quad$ Broad money (M2), as percent of GDP, as percent change, and in local currency. ${ }^{11}$

- $\quad$ Merchandise trade as percent of GDP.

- Imports of goods as percent of GDP.

${ }^{11}$ For Euro-zone members, this aggregate was created from bank deposit aggregates, and excludes the cash component which is typically a very small fraction of M2 for those countries for which the data exists. 
- Imports of services as percent of GDP.

- $\quad$ Portfolio investment in equity, in current U.S. dollars.

- $\quad$ Public debt to GDP.

- $\quad$ Real interest rate in percent (ex post definition).

- $\quad$ Real effective exchange rate (IMF definition), as 5 year cumulative percent change, and as deviation from 10 year average.

- $\quad$ Remittances received as percent GDP.

- $\quad$ Savings as percent of GNI.

- $\quad$ Domestic savings as percent of GNI.

- $\quad$ Trade balance as percent of GDP.

- $\quad$ Exports of goods as percent of GDP.

- $\quad$ Exports of Services as percent of GDP.

\section{List of Countries in the Sample}

Albania, Angola, Argentina, Armenia, Australia, Austria, Azerbaijan, Bangladesh, Belarus, Belgium, Bolivia, Botswana, Brazil, Bulgaria, Cambodia, Canada, Cape Verde, Chile, China, Colombia, Costa Rica, Croatia, Czech Republic, Denmark, Dominica, Egypt, Arab Rep., Estonia, Finland, France, Gambia, The, Georgia, Germany, Greece, Guatemala, Guyana, Haiti, Honduras, Hong Kong, China, Hungary, Indonesia, Ireland, Israel, Italy, Jamaica, Japan, Jordan, Kazakhstan, Kenya, Korea, Rep., Kyrgyz Republic, Lao PDR, Latvia, Lebanon, Lithuania, Luxembourg, Macedonia, FYR, Mexico, Moldova, Morocco, Mozambique, Namibia, Netherlands, New Zealand, Nicaragua, Paraguay, Peru, Philippines, Poland, Portugal, Romania, Russian Federation, Saudi Arabia, Seychelles, Singapore, Slovak Republic, South Africa, Spain, Sri Lanka, St. Vincent and the Grenadines, Swaziland, Sweden, Switzerland, Tanzania, Thailand, Tonga, Tunisia, Turkey, Uganda, Ukraine, United Kingdom, United States, Uruguay, Vietnam, Yemen, Rep., Zambia. 


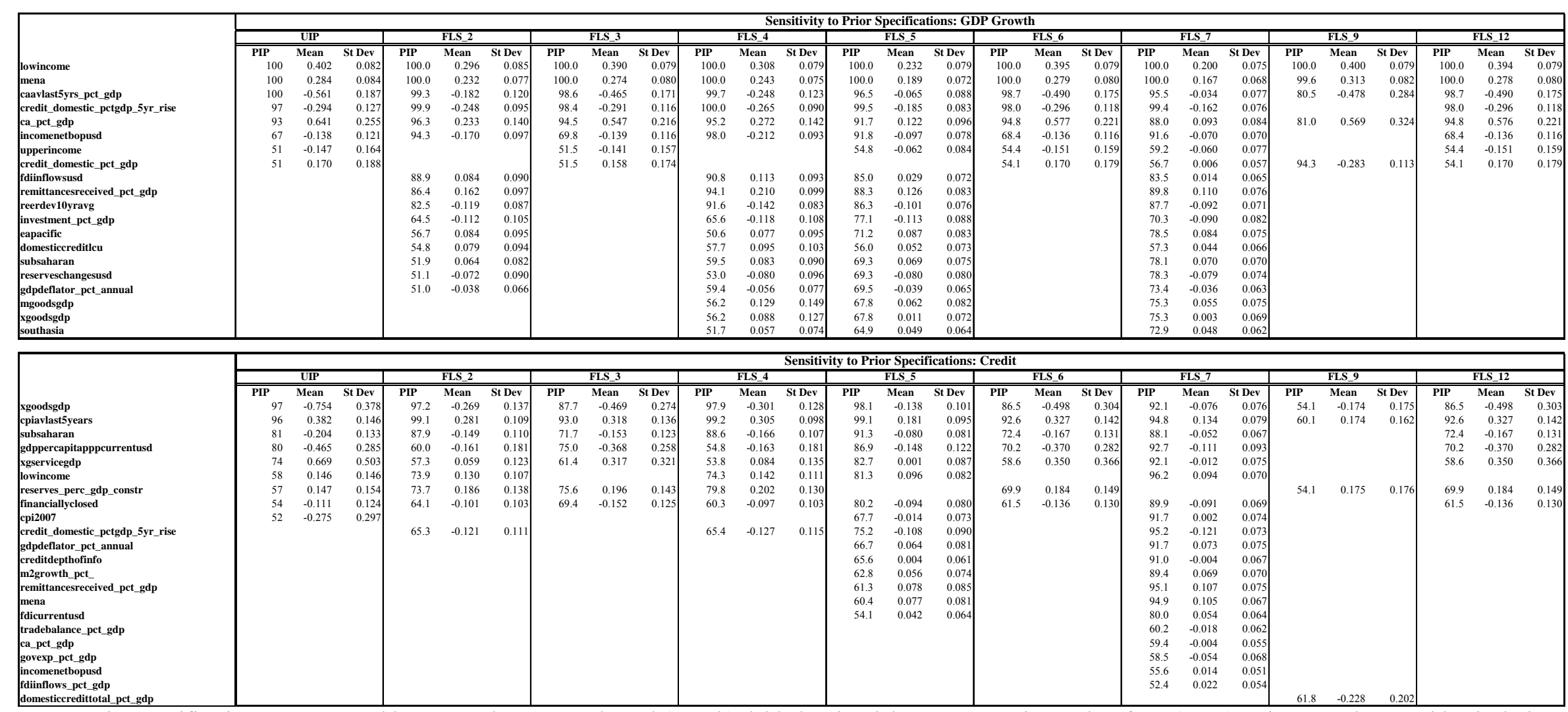

Notes: Prior specifications as suggested by Fernandez, Ley and Steel (2001b), labled as in Eicher Papageorgiou and Raftery (2011). Priors 9 and 10 are identical given the nature of our data. Data dependent priors are excluded. 